\title{
The Protective Role of Alpha Lipoic Acid Against pesticides Induced Testicular Toxicity- Histopathological and Histochemical Studies
}

Azza M. Gawish

Department of Zoology, Faculty of Science, Cairo University, Giza, Egypt

\begin{abstract}
The present study aimed to investigate the efficiency of alpha-lipoic acid (ALA) as natural antioxidant in ameliorating some of changes induced by intoxication with a mixture of well known pesticides used in our agricultural media. Four groups of male rats were treated as follows untreated control animals, (p-mix, consists of 1/60LD50 chloropyrifos (2mg/ $\mathrm{Kg} \mathrm{b.wt)} 1 / 200 \mathrm{LD} 50$ of fenitrothion $(2.5 \mathrm{mg} / \mathrm{km} \mathrm{b.wt})$ as used in agriculutural environment and ALA 200mg/animal of alpha lipoic acid, (P-mix+ALA). Histological observation of the intoxicated rats revealed significant alterations in the testis tissue of $\mathrm{P}$ mix. treated group including focal mild testicular damage, blood hemorrhage and hypospermatogensis, necrosis and atrophy. The degree of fibrosis was encountered using masson-trichrome stain technique which revealed various fibrosis grades between the control and treated testes tissues upon the exposure to the insecticides. TUNEL technique showed an increase in the incidence of positive apoptotic cells between the spermatogonial and germ cells. Also complete depletion of the level of acid phosphatase enzyme which involved in the testosterone biosynthesis. The treatment with alpha lipoic acid showed many degrees of improvements in the seminiferous tubules, spermatogenic germ cells and the interstitial cells. Also decrease in the grades of fibrosis between testis tissues. Conclusion: The biochemical, hiopathological, reports supported that the pesticides have many implicated toxic changes on the testes tissues and the antioxidants like alpha lipoic acid obtained many trials to get ameliorative effects on the toxicity of pesticides.
\end{abstract}

Keywords: Pesticides; Reproduction; Apoptosis; Fibrosis; Antioxidants

\section{Introduction}

Chlorpyrifos, first introduced into the marketplace in 1965, has been widely used globally as an insecticide to control crop pests in agriculture, reduce household pests such as termites, reduce insect damage, and for mosquito control. Fenitrothion is approved as a broad-spectrum organophosphorus pesticide. Its toxicity was first evaluated by 1969 . Problems associated with pesticides hazards to man and environment are not confined to the developing countries, but extended to developed nations and still facing some problems in certain locations [1]. It has many structural actions of insecticides as the inhibition of the release of the acetylcholonesterase at the synaptic junction [2]. Several studies showed that organophosphorous as malathion and chlorpyrifose induced various physiological, biochemical, immunological and histological changes in experimental animals [3]. The widespread usage of organophosphates has stimulated research to the existence of effects related with their reproductive toxic activity [4].

Hileman [5] reported that fenitrithione have the potential to cause reproductive toxicity in animals, affect human reproduction. Okamura and Presibella [6-7] showed some pathological effects of pesticides on the reproductive system of experimental animals. Chlorpyrifose had been obtained testicular damage, damage to sperm production, and reduction in testosterone levels when fed to adult male rats [8]. There is growing concern that pesticide as chlorpyrifose had estrogenic property, may be causing a variety of reproductive disorders in wildlife and human population [9].

Gangadharan [10] reported that organophosphorous have been shown to produce reactive oxygen species (ROS) in both intra and extra cellular spaces, resulting in decline of sperm count and infertility in wildlife and human. Chlorpyrifos was showed severe testicular damage and results in reduction in sperm count affecting fertility
[11]. Chlorpyrifos (CPF) and Fenitrothion, are organophosphorous insecticides, have postulated a possible role for the generation of free radicals and induction of oxidative stress [12]. Suskind [13] reported a significant correlation between increased fibrosis and both reduced tubular diameter and fewer germ cells.

Apoptosis or programmed cell death is an active process controls cell numbers in a variety of tissues and at various phases of germ cell development [14]. Many studies reported that many organophosphorous like chlorpyrifose caused withdrawal of gonadotropins and/or testosterone which enhances the germ cell degeneration and apoptosis of germ cells in the testis [14-17].

Lipoic acid is an organ sulfur compound, which is an essential cofactor for many enzyme complexes and the the amount of lipoic acid present is very low. Naturally occurring lipoic acid is always covalently bound and not immediately available from dietary sources. Studies are generally dealing with the biological consequences of lipoic acid administration and its derivatives in cases associated with oxidative stress [18-20]. An attempt was made to elucidate the possible protective effect of-lipoic acid treatment on pesticidesinduced physiological and histopathological alterations in rats with testicular toxicity. Chlorptrifose exposed rats showed abnormal levels of antioxidants enzymes In contrast, rats pretreated with lipoic

Corresponding author: Azza M. Gawish, Department of Zoology, Faculty of Science, Cairo University, Giza, Egypt, E-mail: Azzagawish@ymail.com

Received August 16, 2010; Accepted October 18, 2010; Published October 21, 2010

Citation: Gawish AM (2010) The Protective Role of Alpha Lipoic Acid Against pesticides Induced Testicular Toxicity- Histopathological and Histochemical Studies. J Aquac Res Development 1:101. doi:10.4172/2155-9546.1000101

Copyright: (C) 2010 Gawish AM. This is an open-access article distributed unde the terms of the Creative Commons Attribution License, which permits unrestricted use, distribution, and reproduction in any medium, provided the original author and source are credited. 
acid showed normal lipid peroxidation and antioxidant defenses. These findings indicate a cytoprotective role of lipoic acid in this experimental model of testicular toxicity [21]. Present study was taken to assess the effects of chlorpyrifos and fentrithion on testes, the main organ of male reproduction and the possible ameliorative effect of naturally occurring antioxidants like alpha lipoic acid.

\section{Materials and Methods}

\section{Animals and experimental design}

Animals: Male albino rats Rattus norvegicus (3-4) month's age, weighing between 150-180 g were used. Animals were supplied by the breeding unit of the Egyptian Organization for the Biology and Vaccine Production, Egypt. The animals were housed in plastic cages, fed ad libitum and allowed to adjust to the new environment for two weeks before starting the experiment. The rats were housed at $23 \pm$ $2^{\circ} \mathrm{C}$ dark/light cycle.

\section{Chemicals}

Chlotpyrifos: Pyriban(chlorpyrifos48\%EC)(O,O-Diethyl-O(3,5,6trichloro-2-pyridyl phosphorothioat) was supplied by El Help company for pesticide industry- Egypt.

Fenitrothion: Sumithion (Fenitrothion 50\% EC) (O,O-dimethyl O-4nitro-m-tolyl phosphorothioate) was purchased from Kaffer Elzayat Co. for Insecticide Ind. Kaffr Elzayat, Egypt.

Antioxidant used: Alpha lipoic acid.

\section{Experimental Design}

All animals were treated according to the standard procedures laid down by OECD guidelines 407 (1992) repeated dose 28 days oral toxicity study in rodents. Animals were randomly divided into six experimental groups, five animals each as follows:

Group 1 (control): Each animal in this group was given distilled water $(1 \mathrm{ml} /$ animal) by gastric incubation every day for 28 days.

Group 2 (P-mix): rats were orally treated via gastric intubation with mixture of pesticides mixture contain $\left(1 / 60 \mathrm{LD}_{50}\right.$ chloropyrifos $\left(2 \mathrm{mg} / \mathrm{Kg}\right.$ b.wt, $1 / 200 \mathrm{LD}_{50}$ of fenitrothion $=2.5 \mathrm{mg} / \mathrm{k} \mathrm{gm} \mathrm{b.wt} \mathrm{every} \mathrm{day}$ for 28 consecutive days.

Group 3 (ALA): rats were orally supplemented with $60 \mathrm{mg} / \mathrm{Kg}$ for 28 days and served as +ve control. 4-Group (P-mix + ALA): rats were orally supplemented with $(60 \mathrm{mg} / \mathrm{kg})$ ALA 1 hour after intoxication with pesticides mixture.

\section{Sampling}

Blood samples collected from the retro-orbital plexus vein according to Schermer (1967). On heparinzed tubes at 28 days of treatment periods, plasma samples were separated by centrifugation of the blood samples at $3600 \mathrm{rpm}$ for $15 \mathrm{~min}$. Plasma samples were kept at $-20{ }^{\circ} \mathrm{C}$ for subsequent use. At the end of the experiment, animals were dissected and samples of the testis were subjected to the histopathological and histochemical studies.

Biochemical assay: Malondaldehyde (MDA) enzyme was measured according to Ohkawa et al., [22], in the plasma after incubation at $95^{\circ} \mathrm{C}$ with thiobarbituric acid in aerobic conditions ( $\mathrm{pH} 3.4)$. Testosterone hormone level was measured in the plasma according to Tremblay et al., [23].

Histological studies: Animals were sacrificed after 24 hour of treatment. The testis was dissected and fixed immediately in neutral buffered formalin $(10 \%)$ and paraffin sections were prepared and stained with hematoxylin and eosin. and Masson-trichrome stain was used showing collagen and elastic fibers changes according to Bancroft and Gamble [24].

\section{2- Assessment of apoptosis}

Evaluation of apoptosis in testis tissue homogenate was achieved by quantification of cytoplasmic histone-associated DNA fragments using cell death Detection ELISA plus kit (Roche). One ml of testis tissue was transferred into 1 volume incubation buffer (7\% paraformaldehyde) and homogenized. According to the kit manufacturer's guidelines (Roche), homogenized samples were centrifuged at $13000 \mathrm{rpm}$ for $10 \mathrm{~min}$ at $4^{\circ} \mathrm{C}$, the supernatant was removed carefully, and the pellet was resuspended in $200 \mu \mathrm{l}$ incubation lysis buffer, and incubated for $30 \mathrm{~min}$ at room temperature. It should be noticed that several dilutions of testis tissue were assayed to determine the appropriate concentration required for ELISA as a preliminary test. Then the lysate was centrifuged at 200x g for $10 \mathrm{~min}$, the supernatant (cytoplamic fraction) $20 \mu \mathrm{l} /$ well was transferred carefully into the streptavidincoated micro-titer plate (MTP) for analysis; samples were added in duplicates. Positive, blank and background controls were treated similarly as the samples. The immunoreagent was prepared by mixing $1 / 20$ volume antihistone-biotin with $1 / 20$ volume anti-histone with $18 / 20$ volume incubation buffer (v:v:v), then $80 \mu \mathrm{l} /$ well of the prepared reagent were added to MTP. The plate was incubated (covered with adhesive foil) on MTP shaker under gentle shaking for 2 hrs at room temperature. Then, the solution was well rinsed in $250 \mu \mathrm{l}$ incubation buffer. The reaction was visualized by adding $100 \mu \mathrm{l} /$ well of the freshly prepared substrate ABTS, incubated for $15 \mathrm{~min}$ on a plate shaker at $250 \mathrm{rpm}$ until the colour development is sufficient for photometric analysis. The absorbance was recorded at $405 \mathrm{~nm}$ against ABST as a blank (reference wave length approx. $490 \mathrm{~nm}$ ). Unless otherwise stated, all reagents and supplements were supplied with the kit. The concentration of nucleosomes in the sample reflects the amount of cell death. Increases in DNA fragmentations over control values (blank and background) were measured and expressed as $\mathrm{OD}_{405-490}$.

\section{TUNEL staining}

To detect cells undergoing apoptosis, the tissue sections were stained according to the TUNEL procedure [25], with some modifications. Briefly, the testes tissues was immediately fixed in $4 \%$ paraformaldhyde at $4^{\circ} \mathrm{C}$ for $20-22 \mathrm{~h}$ and embedded in paraffin. The tissue was sectioned at $4 \mu \mathrm{m}$, dewaxed, rehydrated, and digested with $20 \mu \mathrm{g} / \mathrm{ml}$ of proteinase $\mathrm{K}$ (Sigma). Endogenous peroxidase was blocked by treatment in $0.3 \%$ hydrogen peroxide. The sections were then rinsed in water and incubated with $50 \mu \mathrm{l}$ of terminal deoxynucleotidyl transferase buffer in a moist chamber at $37^{\circ} \mathrm{C}$ for $60 \mathrm{~min}$. The sections were then rinsed and $50 \mu \mathrm{l}$ converter-POD was added on each tissue sample, covered, and incubated for $30 \mathrm{~min}$ at $37^{\circ} \mathrm{C}$. For colour development the slides were rinsed in PBS, then $50 \mu \mathrm{l}$ DAB-substrate (Roche) solution were added, incubated in dark for $10 \mathrm{~min}$ at room temperature, washed, counterstained with haematoxylin, dehydrated and finally coverslips were mounted.

Histochemical study: The specimens were subjected to the fixation with froml - calcium and acid phosphatase was detected due to Gomori-lead method in which acid phosphatase activity acquire black colour and the nuclei acquired green colours according to Bancroft and Stevens.

\section{Result}

\section{Biochemical studies}

The expressed data in (Table 1) declared that in addition to the 
Citation: Gawish AM (2010) The Protective Role of Alpha Lipoic Acid Against pesticides Induced Testicular Toxicity- Histopathological and Histochemical Studies. J Aquac Res Development 1:101. doi:10.4172/2155-9546.1000101

Page 3 of 7

classical mechanism of pesticides there is an enhancement for the free radicals that expressed by significant elevation in oxidative stress biomarker malondialdehyde (MDA) versus control at $\mathrm{p}<0.05$. On the other hand, consecutive supplementation with ALA for 28 days alone or in combination with pesticides induced observable significant reduction in plasma MDA level, this significant was versus control and $\mathrm{P}$-mix treated groups at $\mathrm{p}<0.05$. As regards to plasma testosterone level repeated intoxication with $\mathrm{p}$ mix induced remarkable significant reduction versus control in plasma testosterone level at $p<0.05$.). However, supplementation with ALA improves the toxic effect of $p$ mix that was significant versus control and P- mix groups.

\begin{tabular}{|c|c|c|c|c|}
\hline \begin{tabular}{|l|l|l|} 
Parameter & Groups \\
\end{tabular} & Con. & P-Mix & ALA (+ ve C) & ALA+ P-mix \\
\hline MDA $(\mu \mathrm{mol} / \mathrm{dl})$ & $17.22 \pm 1.77$ & $31.71 \pm 1.66^{\mathrm{a}}$ & $19.97 \pm 3.57$ & $21.96 \pm 2.99$ \\
\hline Testosterone (ng/dl) & $211.699 \pm 20.11$ & $143.043 \pm 11.16^{\mathrm{a}}$ & $207.699 \pm 16.22$ & $192.779 \pm 19.27^{\mathrm{ab}}$ \\
\hline $\begin{array}{l}\text { All data were expressed } \\
\text { asignificance difference } \\
\text { bsignificance difference } \\
\text { 'significance difference } \\
\text { MDA: malondialdehyde }\end{array}$ & $\begin{array}{l}\text { as mean } \pm \text { SE. } \\
\text { versus control at } \\
\text { versus control at } \\
\text { versus control at } \\
\end{array}$ & $\begin{array}{l}P<0.05 \\
P<0.05 \\
P<0.05\end{array}$ & & \\
\hline
\end{tabular}

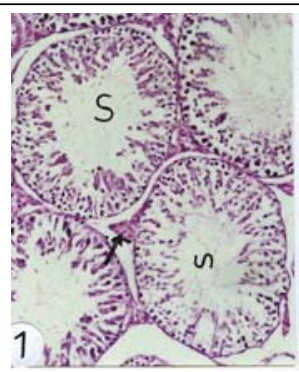

Figure 1: Photomicrograph of testis section of untreated rat showed normal appearance of testis structure (Arrows) and smeiniferous tubules (S).

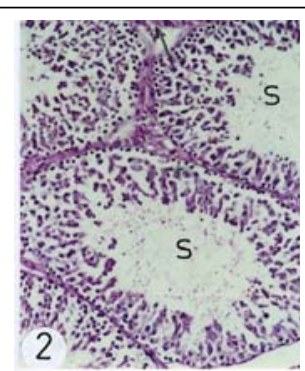

Figure 2: Photomicrograph of testes section of rat treated with $(60 \mathrm{mg} / \mathrm{kg})$ alpha lipoic acid showed nearly normal architecture of seminiferous tubules and interstitial cells (arrows).

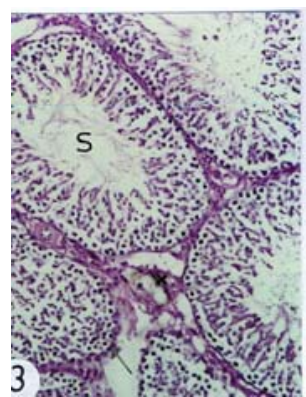

Figure 3: Photomicrographs of testes sections of rats treated with insecticide mixture of (1/60 of LD50 of chlorpyrifose and 1/200 LD50 of fenitithione) showed infoldings of the membranes of seminiferous tubules, degeneration of the spermatogenesis process and hemorrhage between the seminiferous tubules (arrows)
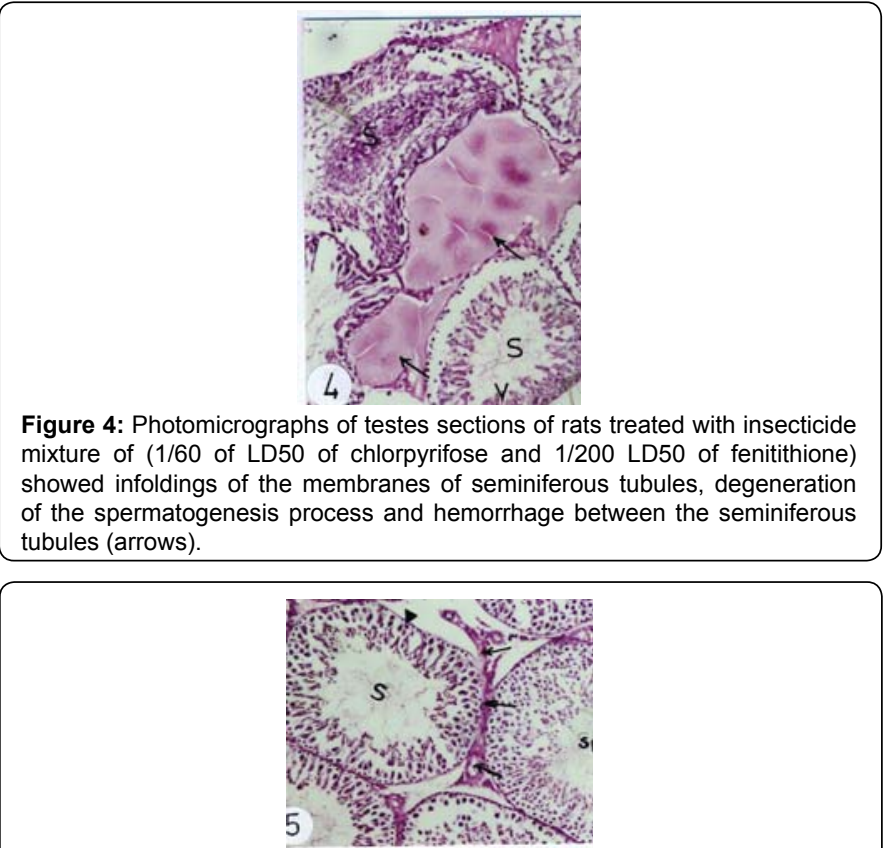

Figure 5: Photomicrograph of testes sections of rats also treated with pesticide mixture obtained more proliferation within the interstitial cells (arrows).

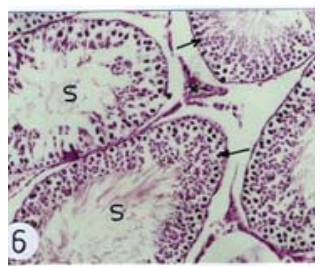

Figure 6: Photomicrograph of testes sections of rats intoxicated with the pesticide mixture and treated with ALA revealed some amelioration of the hypospermatogonia in the seminiferous tubules (S6) and giant cells between the Leydig cells (arrows).

\section{Histopathological observations}

A) Examination of sections of the testes with haematoxylin and eosin stain revealed normal architecture of seminiferous tubules, normal arrangement of spermatogenic cells germ cells and well arranged and distributed interstitial cells in the peritubular areas (Figure 1). The second group of rats was treated with $(60 \mathrm{mg} / \mathrm{kgm}$ b.wt.) of alpha-lipoic acid served as positive control showed nearly normal appearance of the seminiferous tubules and Leydig cells (Figure 2). Upon the toxicity with (P-mix, consists of, 1/60LD50 chloropyrifos ( $2 \mathrm{mg} / \mathrm{Kg}$ b.wt) $1 / 200 \mathrm{LD} 50$ of fenitrothion $(2.5 \mathrm{mg} / \mathrm{kgm}$ b.wt) of pesticides mixture, the testes tissues appeared with many foldings of the basement membrane of the seminiferous tubules, highly degeneration of the interstitial cells (Figure 3). Also, severe disorganized and atrophy of tubules and complete blood hemorrhage (Figure 4), some giant and necrotic cells appeared between the interstitial cells (Figure 5). When the rats treated with alpha- lipoic acid after the toxicity with the pesticides mixtures, the testis tissues revealed some degeneration between the germ cells of the tubules and well arranged interstitial cells (Figure 6 and Figure 7) and well organized.

B Fibrosis: Staining of the testes sections with Masson-trichrome stain showed normal thickening of the walls surrounding the testis tissues (Tunica albuginea) (Figure 8). The testis tissue of the animals treated with $(60 \mathrm{mg} / \mathrm{kg}$ b.wt.) of lipoic acid showed mild 
Citation: Gawish AM (2010) The Protective Role of Alpha Lipoic Acid Against pesticides Induced Testicular Toxicity- Histopathological and Histochemical Studies. J Aquac Res Development 1:101. doi:10.4172/2155-9546.1000101

Page 4 of 7

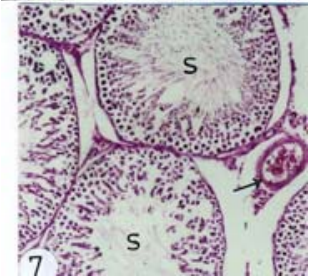

Figure 7: Photomicrograph of testes sections of rats intoxicated with the pesticide mixture and treated with ALA revealed some amelioration of the hypospermatogonia in the seminiferous tubules (S6) and giant cells between the Leydig cells (arrows).

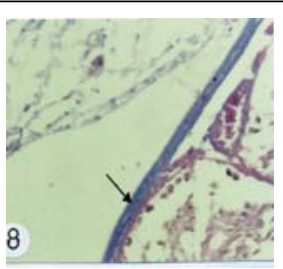

Figure 8: Photomicrograph of testis section of untreated rat stained with masson trichrome stain showed the tunica albuginea normally arranged (arrows).

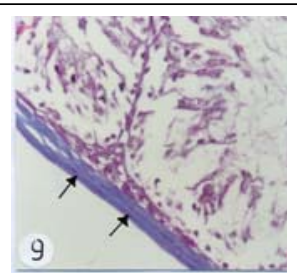

Figure 9: Photomicrograph of testes section of rat treated with $(60 \mathrm{mg} / \mathrm{kg})$ alpha lipoic acid showed nearly normal architecture of seminiferous tubules and interstitial cells (arrows).

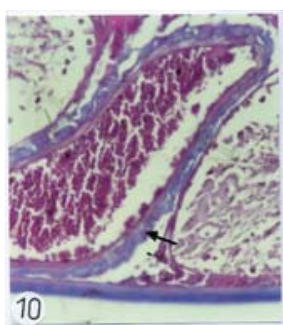

Figure 10: Photomicrographs of testes sections of rats treated with insecticide mixture of (1/60 of LD50 of chlorpyrifose and 1/200 LD50 of fenitithione) showed high degree of fibers around the seminiferous tubules (arrows 10) and around the testis (arrows 11).

fibrosis around the testis section (Figure 9). The pesticides mixture treatment obtained higher grades of fibrosis surrounding the testis section (Tunica albuginea) and in the peritubular areas (Figure 10 and Figure 11). Supplementation of alpha lipoic acid after the toxicity of pesticides mixture showed testis tissues with minimal fibrosis (Figure 12).

\section{Immunohistochemical results}

Testes sections of all groups were subjected to terminal deoxynucleotidyl transferase-mediated dUTP nick end labeling of tissue sections TUNEL for the detection of apoptosis. The testis tissue of the untreated control rats showed normal significant positive cells (Figure 13). Upon supplementation with alpha lipoic acid alone the testis tissue revealed mild increase in the positive cells between their germ cells (Figure 14). The testis section of the animals intoxicated with pesticides mixture obtained significant highly positive cells between all the stages of spermatogenesis cells (Figure 15). Mild improvement of the apoptotic positive cells was recorded within the testis tissue of the rats treated with alpha lipoic acid after the intoxication with pesticides mixture (Figure 16).

\section{Histochemical observations}

Acid phosphatase enzyme was detected in all testes sections of the animals using Gomori lead method. Untreated animals recorded the distribution of acid phosphatase in the primary and secondary spermatocytes as brown granules (Figure 17). The animals treated with alpha-lipoic acid (served as+control group) showed nearly normal level of the brown granules of acid phosphatase enzyme (Figure 18). Animals treated with the pesticides mixture obtained complete

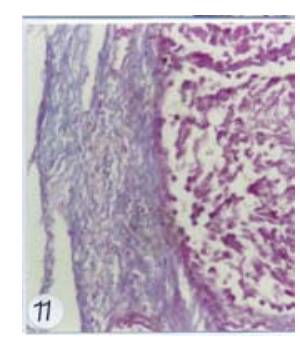

Figure 11: Photomicrographs of testes sections of rats treated with insecticide mixture of (1/60 of LD50 of chlorpyrifose and 1/200 LD50 of fenitithione) showed high degree of fibers around the seminiferous tubules (arrows 10) and around the testis (arrows 11).

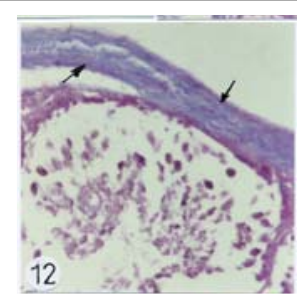

Figure 12: Photomicrograph of testes sections of rats intoxicated with the pesticide mixture and treated with ALA revealed nearly normal appearance of the fibers with minimal increase comparing to untreated control animals.

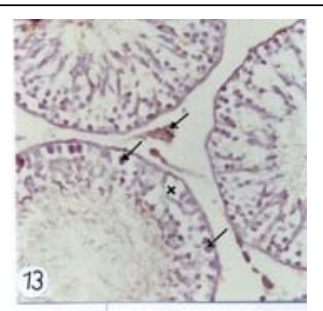

Figure 13: Photo graph of testis section tissue of untreated rat showed normal positive cells between the spermatogenesis cells (arrows).

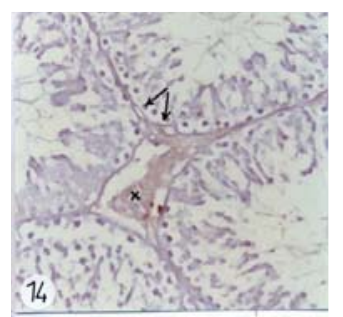

Figure 14: Photomicrograph of testes section of rat treated with $(60 \mathrm{mg} / \mathrm{kg})$ alpha lipoic acid showed some positive cells within germ cells (arrows). 
Citation: Gawish AM (2010) The Protective Role of Alpha Lipoic Acid Against pesticides Induced Testicular Toxicity- Histopathological and Histochemical Studies. J Aquac Res Development 1:101. doi:10.4172/2155-9546.1000101

Page 5 of 7

depletion in the brown granules of acid phosphatase enzyme. (Figure 19) compared to the untreated animals. Alpha - lipoic acid treatment with the pesticides mixture showed mild ameliorative effect on the concentration of the enzyme granules (Figure 20) compared to the pesticides treated group.

\section{Discussion}

The testicular toxicity of insecticides was proven and alternative

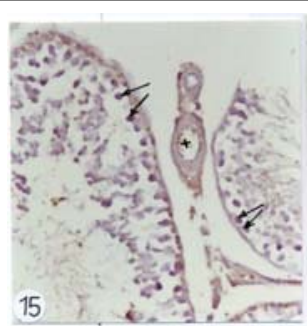

Figure 15: Photomicrographs of testes sections of rats treated with insecticide mixture of (1/60 of LD50 of chlorpyrifose and 1/200 LD50 of fenitithione) showed significant increase in the brown positive cells within the primary stages of germ cells (arrows).

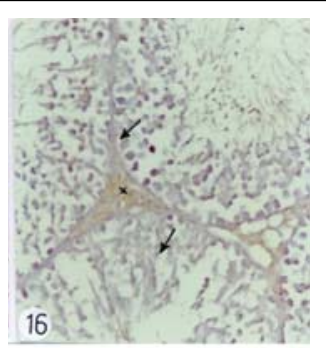

Figure 16: Photomicrograph of testes sections of rats intoxicated with the pesticide mixture and treated with ALA revealed nearly decrease of the positive cells (arrows).

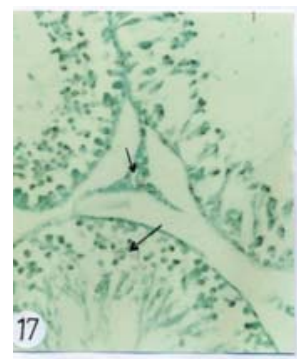

Figure 17: Photo graph of testis section tissue of untreated rat showed normal distribution of the brown granules of the acid phosphatase enzyme within primary stages of spermatogonia (arrows).

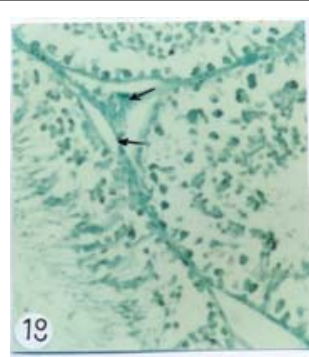

Figure 18: Photomicrograph of testes section of rat treated with $(60 \mathrm{mg} / \mathrm{kg})$ alpha lipoic acid showed normal content of the brown granules within germ cells (arrows).
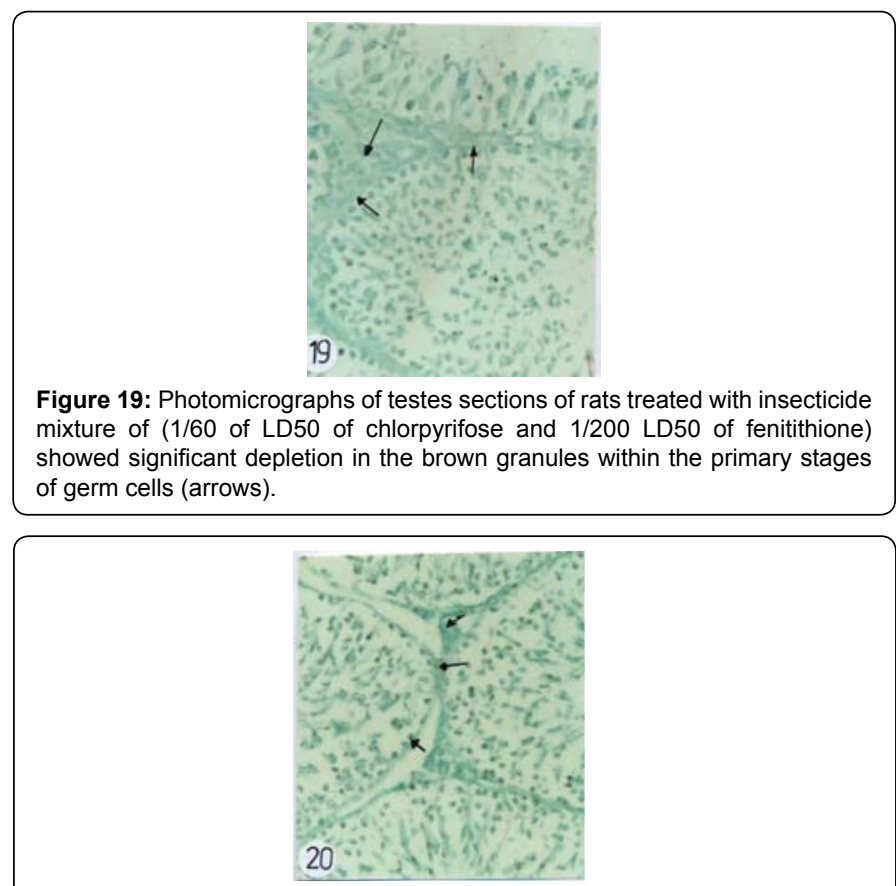

Figure 20: Photomicrograph of testes sections of rats intoxicated with the pesticide mixture and treated with ALA revealed nearly normal view of the acid phosphatase enzyme (arrows).

harmless control strategies should be applied. Insecticides were proven to be induced sever testicular toxicity as shown in the histopathological results which coupled with marked changes of biochemical results. Our results obtained spermatogonial depletion and atrophy due to pesticides toxicities in the seminiferous tubules. We detected desquamated cells in the lumen of seminiferous tubules and vacuolization within germ cells and some tubules contain apoptotic bodies, at the end of treatment, Leydig cells are strongly regressed and spermatozoa are less present in the luminal aspect of the seminiferous tubules. Also thickened basement membrane accompgnied by disappearance of interstitial cells and Leydig cells were proven.

There are several possible mechanisms for the antigonadal actions of organphosphorous in which they may exert a direct inhibitory action on the testis; they may affect the pituitary causing changes in gonadotropin concentration, and may change the concentration of the neurotransmitter acetylcholine [26-27]. The hazardous effect of these pesticides on semen quality continued during the post treatment period, and was dose-dependent[28]. Therefore Roy et al., [2] showed that quinalphos may exert a suppressive effect on the functional activity of accessory sex glands by decreasing testicular testosterone production following inhibition of pituitary gonadotrophins release[29]. Exposure to low level organophosphorous is known to produce a variety of biochemical changes, some of which may be responsible for the adverse biological effects reported in humans and experimental animals [30].

As it was shown that, fibrosis correlates with these histological finding, and implicated with the pathological changes. Fibrosis is probably the end result of an inflammatory process. Cell death also occurs spontaneously at various phases of germ cell development and morphological studies have implicated apoptosis in spermatogonial death appears to play a major role during spermatogenesis [14]. The spermatogenesis in mammals depends on testosterone production 
by Leydig cells in response to stimulation by FSH and LH. FSH increases Sertoli cell synthesis of an androgen binding protein needed to maintain high concentrations of testosterone. LH stimulates testosterone production by the interstitial cells of the testis [31]

Sugar [32] obtained that acid phospatase enzyme plays an important role in the process of cell metabolism, autolysis, differentiation and many related processes and the dilatation of blood capillaries in between seminiferous tubules obtained upon the result of acid phosphatase enzyme activity. The increase in acid phospahatase enzyme activity could be explained on the bases of enhancement of cell membrane permeability with disturbance in the transphosphorylation process as a result of cellular degeneration [3334].

The depletion of the enzymatic antioxidative system strengthens the oxidative damage of membranes plays a significant role in cellular damage into the testes [35-36]. Pesticides may induce oxidative stress, leading to generation of free radicals and alteration in antioxidants, oxygen free radicals, the scavenging enzyme system, and lipid peroxidation [37-38].

Lipoic acid was first postulated to be an effective antioxidant [3942]. It is able to scavenge reactive species in vitro, though there is little or no evidence that this actually occurs in vivo. Alpha Lipoic Acid works both inside the cell and at the membrane level, thereby giving dual protection. [43] obtained the ability of ALA to create a robust shield on the cell membrane of sperm, along with the liquid that surrounds the sperm indirectly enhance the ability of the sperm to tolerate higher volumes of free radical attack. ALA has also been reported to assist the mitochondria's citric cycle; this in turn will increase the level of reduced glutathione, ATP, TCA cycle enzyme and electron transport chain complex activities $[44,20]$. ALA regulation of metabolism, increased availability of mitochondrial co-enzymes and improvement of protection of free radicals are thought to eventually lead to a reduced incidence of mitochondria dysfunction, thus ensuring sufficient ATP for sperm movement [11]. In conclusion, the toxicity of the pesticides mixture was shown atrophy, fibrosis and increase the incidence of the apoptosis on the testes tissues then, on the fertility and spermatogenesis process. Also, alpha lipoic acid treatment revealed mild ameliorative effect on the pathology of testes [45-70].

\section{References}

1. Nuckols JR, Gunier RB, Riggs $P$ (2007) Linkage of California pesticide use reporting data-base spatial land use for exposure assessment. Environ Health Perspec 115: 684-689.

2. Roy TS, Seidler FJ, Slotkin TA (2004) Morphologic effects of subtoxic neonatal chlorpyrifos exposure in developing rat brain: Regionally selective alterations in neurons and glia. Brain Res Dev Brain Res 148: 197-206.

3. Tamura H, Maness SC, Reishman K, Dorman DC, Gray LE, et al. (2001) Androgen Receptor antagonism by the organophosphate insecticide fenitrothion. Toxicol Sci 60: 56-62.

4. Pajoumand A, Jalali N, Abdollahi N, Shadnia S (2002) Survival following severe aluminium phosphide poisoning. J Pharm Pract Res 32: 297-299.

5. Hileman B (1994) Environmental estrogens linked to reproductive abnormalities and cancer. Chem Eng New 31: 19-23.

6. Okamura A, Kamijima M, Shibata E (2005) A comprehensive evaluation of the testicular toxicity of dichlorvos in Wistar rayts. Toxicology 213: 129-37.

7. Presibella KM, Kita DH, Carneiro CB, Andrade AJM, Dalsenter PR, et al. (2005) Reproductive evaluation of two pesticides combined (deltamethrine and endosulfan) in female rats. Reproduc Toxicol 20: 95-101.

8. Afifi NA, Ramadan A, El-Aziz MI, Saki EE (1991) Influence of dimethoate on testicular and epidymal organs, testosterone plasma level and their tissue residues in rats. Dtsch Tierarztl Wochenschr 98: 419-423.

9. Chitra KC, Latchoumycandane C, Mathur PP (1999) Chronic effect of endosulfan on the testicular functions of rat. Asian J Andrology 1: 203-206.

10. Gangadharan B, Murugan MA, Mathur PP (2001) Effect of methoxychlor on antioxidant system of goat epididymal sperm in vitro. Asian J Androl 3: 285-288.

11. Ibrahim SF, Khairul O, Srijit D, Abas MO, Norzaiti A, et al. (2008) A Study of the Antioxidant Effect of Alpha Lipoic Acids on Sperm Quality Clinics. 63: 545-550.

12. Tuzmen N, Candan N, Kays E, Demiryas N (2008) Biochemical effects of chlorpyrifos and deltamethrin on altered antioxidative defense mechanisms and lipid peroxidation in rat liver. Cell Biochem Funct 26: 119-124.

13. Suskind A, Hayner-Buchan A, Feustel PJ (2007) Analysis of human undescended testes. B J U International 101: 1441 - 1445.

14. Bartke A (1995) Apoptosis of male germ cells, a generalized or a cell type-specific phenomenon? Endocrinology 136: 3-4.

15. Billig H, Furuta I, Rivier C, Tapanainen J, Parvinen M, et al. (1995) Apoptosis in testis germ cells: developmental changes in gonadotropin dependence and localization to selective tubule stages. Endocrinology 136: 5-12.

16. Henriksen K, Hakovirta H, Parvinen M (1995) Testosterone inhibits and induces apoptosis in rat seminiferous tubules in a stage-specific manner: in situ quantification in squash preparations after administration of ethane dimethane sulfonate. Endocrinology 136: 3285-3289.

17. Hikim APS, Wang C, Leung A, Swerdloff RS (1995) Involvement of apoptosis in adult rats after gonadotropin-releasing hormone antagonist treatment. Endocrinology 136: 2770-2775.

18. Gotz ME, Dirr A, Burger R, Janetzky B, Weinmuller M, et al. (1994) Effect of lipoic acid on redox state of coenzyme $Q$ in mice treated with 1-methyl-4- phenyl1,2,3,6-tetrahydropyridine and diethyldithiocarbamate. Eur J Pharmacol 266 291-300.

19. Han D, Handelman G, Marcocci L, Sen CK, Roy S, et al. (1997) Lipoic acid increases de novo synthesis of cellular glutathione by improving cystine utilization. Biofactors 6: 321-338.

20. Henriksen EJ (2006) Exercise training and the antioxidant alpha-lipoic acid in the treatment of insulin resistance and type 2 diabetes. Free Radic Biol Med 40: 3-12.

21. Selvakumar P, Lakshmikuttyamma A, Kanthan R, Kanthan SC, Dimmock JR, et al. (2004) High expression of methionine aminopeptidase 2 in human colorectal adeno carcinomas. Clin Cancer Res 10: 2771-2775

22. Ohkawa H, Ohishi N,Yagi K (1979) Assayof lipid peroxidases in animal tissues by thiobarbituric acid reaction. Anal Biochem 95: 351-8.

23. Tremblay RR (2001) Practical consequences of the validation of a mathematical model in assessment of partial androgen deficiency in the aging male using bioavailable testosterone. The Aging Male 4: 23-9.

24. Bancrot JD, Stevens (2002) Theory and Practice of Histological Techniques (Fourth Edition), Queen's Medical Center, Notingham, University Hospital NHS Trust.

25. Gavrieli Y, Sherman Y, Ben-Sasson SA (1992) Identification of programmed cell death in situ via specific labeling of nuclear DNA fragmentation. J Cell Biol Nov 119: 493-501.

26. Sarkar R, Mohanakumar KP, Chowdhury M (2000) Effects of an organophosphate pesticide, quinalphos, on the hypothalamo-pituitary-gonadal axis in adult male rats. J Reprod Fertil 118: 29-38.

27. Serin M, Gülbaş H, Gürses I, Erkal HS, Yücel N (2007) The histopathological evaluation of the effectiveness of melatonin as a protectant against acute lung injury induced by radiation therapy in a rat model. Int J Radiat Biol 83: 187-93.

28. Cakir S, Sarikaya R (2005) Genotoxicity testing of some organophosphate insecticides in the Drosophila wing spot test. Food Chem Toxicol 43: 443-450.

29. Prashanthi N, Narayana K, Nayanatara A, Chandra KH, Bairy KL, et al. (2006) The reproductive toxicity of the organophosphate pesticide 0 , 0-dimethyl 0-4nitrophenyl phosphorothioate (methyl parathion) in the male rat. Folia Morpho 65: 309-321.

30. Sultatos LG (1994) Mammalian toxicology of organophosphorous pesticides. J Toxicol Environ Health 43: 271-289.

31. Kackar R, Srivastava MK, Raizada RB (1997) Induction of gonadal toxicity to male rats after chronic exposure to mancozeb. Ind Health 35: 104-111. 
Citation: Gawish AM (2010) The Protective Role of Alpha Lipoic Acid Against pesticides Induced Testicular Toxicity- Histopathological and Histochemical Studies. J Aquac Res Development 1:101. doi:10.4172/2155-9546.1000101

Page 7 of 7

32. Sugár J, Tóth K, Csuka O, Gáti E, Somfai-Relle S (1979) Role of pesticides in hepatocarcinogenesis. J Toxicol Environ Health 5: 183-91.

33. Linder RE, Klinefelter GR, Strader LF, Suarez JD, Roberts NL (1997) Spermatotoxicity of dichloroacetic acid. Reprod Toxicol 11: 681-8.

34. Ibrahim NA, El-Gamal BA (2003) Effect of diazinon, an organophosphate insecticide, on plasma lipid constituents in experimental animals. J Biochem Mol Biol 36: 499-504.

35. Parasmthi K, Muralithara J, Rajini P (2005) Fenvalerate induced oxidative damage inrat tissue and its attenuation by dietary sesame oil. Food Chem Toxico 43: 299- 306

36. Qu JH, Hong X, Chem JF, Wang Y, Sun H (2008) Fenvalerate inhibits progesterone production through cAMP- dependent signal pathway. Toxicol Lett 176: $31-39$.

37. Banerjee BD, Seth V, Battacharya A, Pasha ST, Chakrabory AK (1999) Biochemical effects of some pesticides on lipid peroxidation and free radical scavengers. Toxicol Lett 107: 33-47.

38. Etemadi-Aleagha A, khgari M, Abdollahi M (2002) A brief review on oxidative stress and cardiac diseases. Mid East Pharmac 10: 8-9.

39. Biewenga GP, Haenen GR, Bast A ((1997) The pharmacology of the antioxidant lipoic acid. Gen Pharmacol 29: 315-331.

40. Packer L, Witt EH, Tritschler HJ (1995) Alpha-Lipoic acid as a biological antioxidant. Free Radic Biol Med 19: 227-250.

41. Packer L, Witt EH, Tritschler HJ (1995) Alpha-lipoic acid as a biological antioxidant Free Radic Biol Med 19: 227-250.

42. Packer L, Kraemer K, Rimbach G (2001) Molecular aspects of lipoic and in the prevention of diabetes complications. Nutrition 17: 888-95.

43. Cronan JE, Zhao X, Jiang Y (2005) Function, attachment and synthesis of lipoic acid in Escherichia coli. Adv Microb Physiol 50: 103-46.

44. Reed LJ (2001) A Trail of Research from Lipoic Acid to alpha-Keto Acid dehydrogenase Complexes. J Biol Chem 276: 38329-36.

45. Aliev G, Liu J, Shenk J C, Fischbach K, Pacheco GJ, et al. (2008) Neuronal mitochondrial amelioration by feeding acetyl-L-carnitine and lipoic acid to aged rats. J Cell Mol Med 13: 320-333.

46. Ames BN, Liu J (2004) Delaying the Mitochondrial Decay of Aging with Acetylcarnitine. Ann N Y Acad Sci 1033: 108-116.

47. Astroff AB, FreshWater KJ, Eigenberg DA (1998) Comparative organophosphateinduced effects observed in adult and neonatal Sprague Dawley rats during the conduct of multigeneration toxicity studies. Reprod Toxicol 2: 619-645.

48. Bast A, Haenen GR (1988) Interplay between lipoic acid and glutathione in the protection against microsomal lipid peroxidation. Biochim Biophys Acta 963: 558561.

49. Crammer JS, Avery DL, Grady RR, Kitay JI (1978) Postnatal endocrine dysfunction resulting from prenatal exposure to carbofuran, diazinon or chlordane. J Environ Pathol Toxicol 2: 357-369.

50. Elangovan S, Chidambaram P, Yenjerla M, Palaninathan V (2004) Protective effect of DL-a-lipoic acid in cyclophosphamide induced oxidative injury in rat testis. Reprod Toxicol 19: 163-167.

51. Haenen GRMM, Bast A (1991) Scavenging of hypochlorous acid by lipoic acid Biochem Pharmacol 2: 2244-2246.
52. Haugaard N (1968) Cellular mechanisms of oxygen toxicity. Physiol Rev 48: 311 373

53. Jadaramkunti UC, Kaliwal BB (2002) Dicofol formulation induced toxicity on tests and accessory reproductive organs in albino rats. Bull Environ Contam Toxicol 69: $741-748$

54. Kackar R, Srivastara MK, Raizada RB (1997) Induction of gonadal toxicity to male rats after chronic exposure to mancozob. Ind Health 35: 104-11.

55. Khan SM (2006) Protective effect of black tea extract on the levels of lipid peroxidation and antioxidant enzymes in liver of mice with pesticide - induced liver injury. Cell biochem Funct 24: 327-332.

56. Kozlov AV, Gille L, Staniek K, Nohl H (1999) Dihydrolipoic maintains ubiquinone in the antioxidant active form by two-electron reduction of ubiquinone and oneelectron reduction of ubisemiquinone. Arch Biochem Biophys 363:148-154.

57. Leistra M, Zweers AJ, Warinton JS, Crum SCH, Hand LH, et al. (2003) Fate of the insecticide lambda-cyhalothrin in ditch enclosures differing in vegetation density Pest Manage Sci 60: 75-84.

58. Mathew G, Vijayalaxmi KK, Rahiman MA (1992) Methyl parathion induced sperm shape abnormalities in mouse. Mutat Res 280: 169- 173.

59. Patrick L (2002) (Mercury toxicity and antioxidants: Part 1: role of glutathione and alpha-lipoic acid in the treatment of mercury toxicity. Altern Med Rev 7: 456-71.

60. Pesch S, Bergmann M, Bostedt $\mathrm{H}$ (2006) Determination of some enzymes and Macro-and microelements in stallion seminal plasma and their correlations to semen quality. Theriogenology 66: 307-313.

61. Pryor WA, Houk KN, Foote CS, Fukuto JM, Ignarro LJ, Squadrito GL, et al. (2006) Free radical biology and medicine: it's a gas, man! Am J Physiol Regul Integr Comp Physiol 291: R491- R511.

62. Reuber MD (1985) Carcinogenicity and toxicity of malathion and malaxon Environ Res 37: 119-153

63. Rooney $\mathrm{J}$ (2007) The role of thiols, dithiols, nutritional factors and interacting ligands in the toxicology of mercury. Toxicology 234: 145-156.

64. Rull RP, Ritz B, Shaw GM (2006). Neural tube defects and maternal residentia proximity to agricultural pesticide applications. Am J Epidemiol 163: 743-753.

65. Scholich H, Murphy ME, Sies H (1989). Antioxidant activity of dihydrolipoate against microsomal lipid peroxidation and its dependence on alpha-tocopherol. Biochim Biophys Acta 1001: 256-261.

66. Suresh CJ (2007) Testicular toxicity of chlorpyrifos (an organophosphate pesticide) in albino rat. Toxicol Ind Health 23: 439—444.

67. Soderlund DM, Clark JM, Sheets LP, Mullin LS, Piccirillo VJ, et al. (2002) Mechanism of pyrethroid neurotoxicity: implication for cumulative risk assessment. Toxicology 171: 3-59

68. Tinoco R, Halperine D (1998) Poverty production and health: inhibition of erythrocyte cholinesterase via occupational exposure to organophosphate insecticides in Chipas, Mexico. Arch Environ Health 53: 29- 35.

69. Verma RS (2001) Chlorpyrifos-induced alterations in levels of thiobarbituric acid reactive substances and glutathione in rat brain. Indian J Exp Biol 39: 174-77.

70. Vidyasagar J, Karunakar N, Reddy MS, Rajnarayana K, Surender T, et al. (2004) Oxidative stress and antioxidant status in acute organophosphorus insecticide poisoning. Indian J Pharmacol. 